\title{
Giant Size Foreign Body Reaction at the First Web Space in the Hand: A Case Report
}

\author{
El Birinci Web Aralığında Yabancı Cisim Reaksiyonuna Bağlı Büyük Kitle: Olgu \\ Sunumu
}

(D) Esra Circi, (D) Alican Barış

University of Health Sciences Turkey, i̇stanbul Training and Research Hospital, Clinic of Orthopaedics and Traumatology, i̇stanbul, Turkey

\begin{abstract}
Mass lesions in the hand are common soft tissue problems. This case study aims to examine the giant size foreign body reaction showing atypical features at the first web space in the right hand and to emphasise different diagnosis.
\end{abstract}

Keywords: Foreign body reaction, hand, mass

\section{ÖZ}

Kitle oluşturan lezyonlar elin en yaygın yumuşak doku problemlerinden biridir. Bu olguda sağ el birinci web aralığında yabancı cisim reaksiyonuna bağlı oluşan atipik devasa yumuşak doku kitlesi sunulmuștur. Ayrıca el yumuşak doku patolojilerindeki ayırıcı tanısı vurgulanmıștır.

Anahtar Kelimeler: Yabancı cisim reaksiyonu, el, kitle

\section{Introduction}

Mass lesions in the hand are common soft tissue problems caused by benign skin and soft tissue tumours, foreign body reaction, vascular lesions, granulomatous reactions due to infection, cysts, nerve tumours, premalignant tumours, malignant skin and soft tissue tumours, soft tissue sarcomas, malignant peripheral nerve tumours and metastatic masses $(1,2)$. However, most soft tissue lesions in the hand are benign $(3,4)$. Furthermore, foreign body reactions are reactive traumatic masses. These lesions are the reaction of the organism to the implanted foreign body. The tissue reaction to the foreign body varies depending on the type of foreign body, contact time and anatomic location. Hence, this type of reaction is the isolation method of foreign body (5-7). This case study aims to examine the giant size foreign body reaction showing atypical features in the first web space in the right hand and to emphasise different diagnosis.

\section{Case Report}

Informed consent is taken from the patient for the case presentation below. A 58-year-old male patient with a 1-year mass at the first web space in the right hand (Figures 1,2) that grew in size over time was examined. The physical examination of the mass was painless and palpable. During the evaluation, no signs of infection were found, but the patient's penetrating trauma story was not available. The radiopaque appearance was also not observed during a direct radiographic evaluation. However, ultrasonography examination revealed a $3 \times 2 \mathrm{~cm}$ mass surrounded by hypoechoic halo.

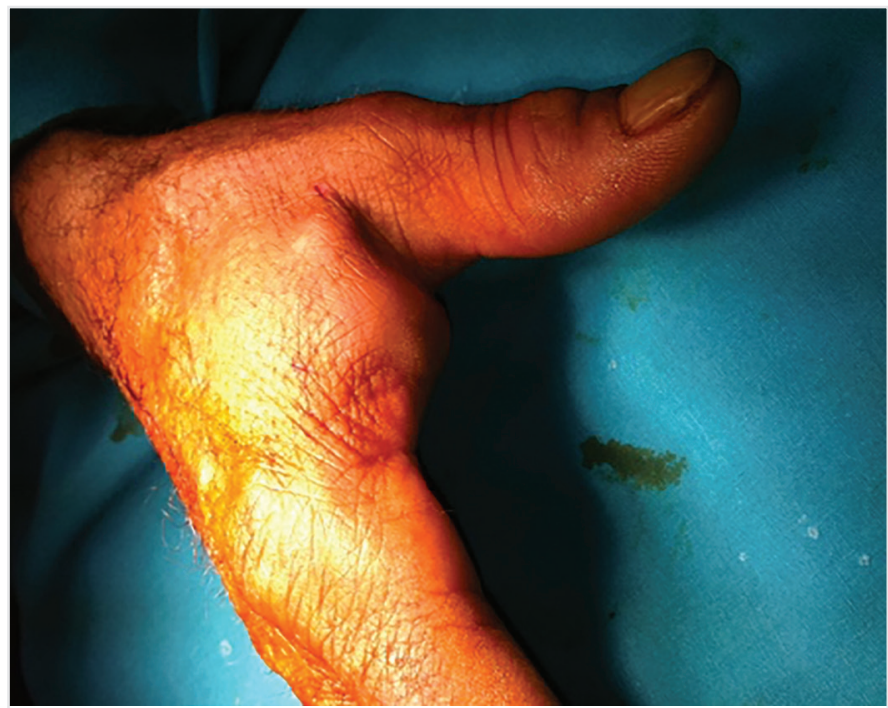

Figure 1. Growing palpable mass at the first web space in the right hand
Address for Correspondence/Yazıșma Adresi: Alican Barış MD, University of Health Sciences Turkey, İstanbul Training and Research Hospital, Clinic of Orthopaedics and Traumatology, İstanbul, Turkey

Phone: +90 5324101881 E-mail: dralicanbaris@gmail.com ORCID ID: orcid.org/0000-0001-6031-6777

Cite this article as/Atıf: Circi E, Barıș A. Giant Size Foreign Body Reaction at the First Web Space in the Hand: A Case Report. İstanbul Med J 2020; 21(Suppl 1): 26-27.

(C) Copyright 2020 by the University of Health Sciences Turkey, Istanbul Training and Research Hospital/Istanbul Medical Journal published by Galenos Publishing House

(C) Telif Hakkı 2020 Sağlık Bilimleri Üniversitesi İstanbul Ĕgitim ve Araştırma Hastanesi/istanbul Tıp Dergisi, Galenos Yayınevi tarafından basılmıștır.

Received/Geliș Tarihi: 21.12.2019 Accepted/Kabul Tarihi: 12.02 .2020 
Thus, an excisional biopsy was planned. Under regional anaesthesia, the mass was reached with an incision parallel to the skin's stria. The encapsulated hard nodule was easily excluded from the surrounding soft tissue (Figure 3). Histopathologic examination showed the inert nature of numerous giant cells surrounding the foreign body.

Pain and cosmetic problems were resolved after surgery. Excision of the mass allowed for prompt resolution. The recurrence of the mass during the 3-year postoperative follow-up was not seen during the physical examination.

\section{Discussion}

In identifying the aetiology, it is important to demonstrate the presence of a foreign body in a radiological evaluation or penetrating trauma

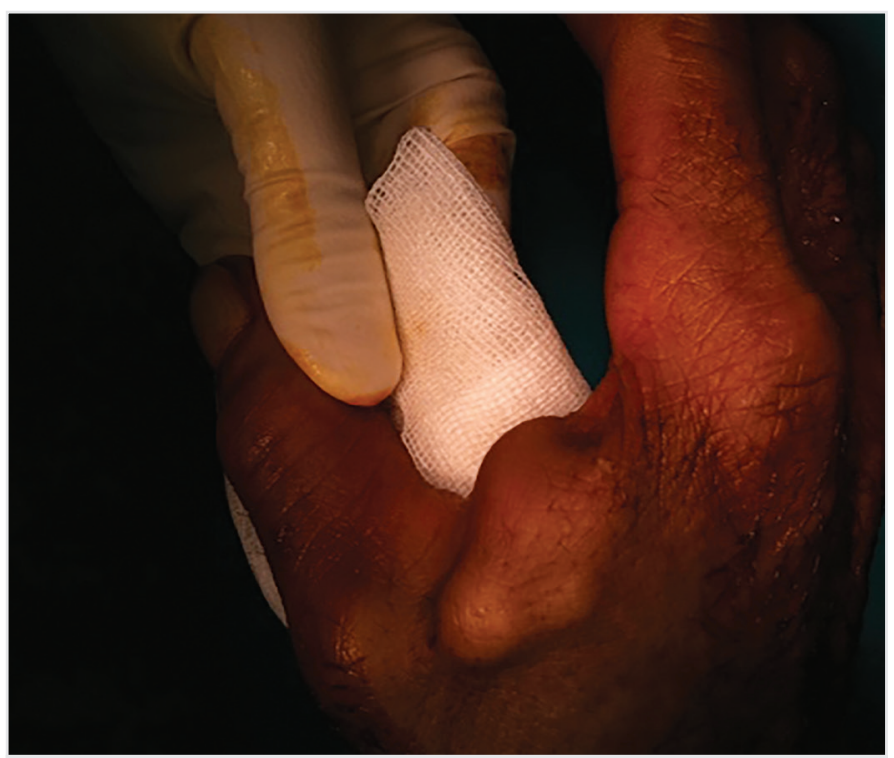

Figure 2. Physical examination of the mass located at the first web space in the right hand

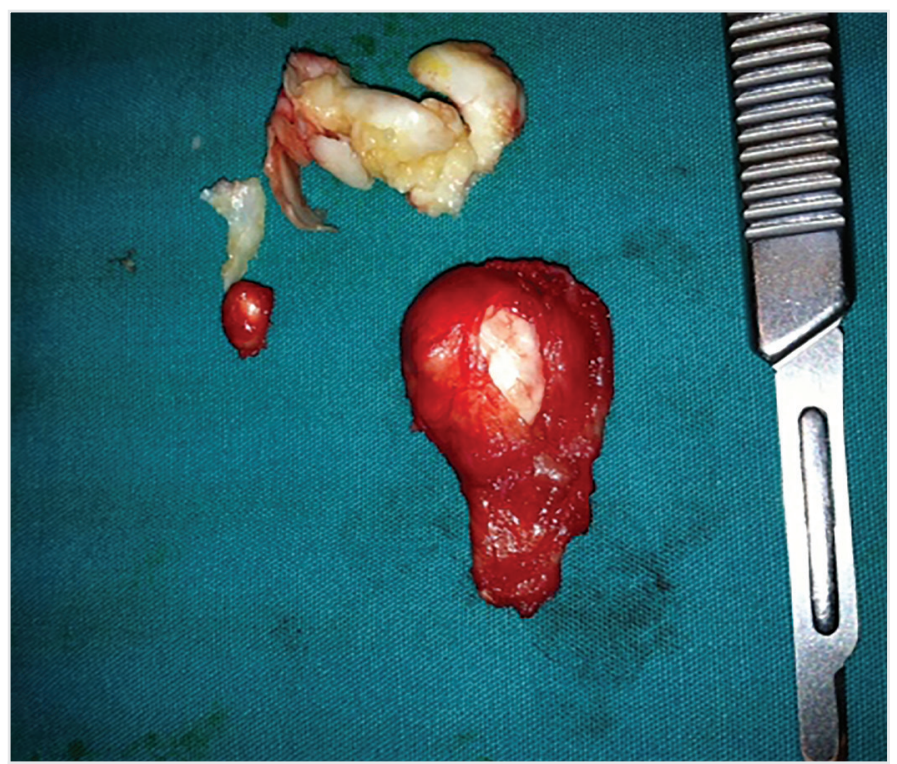

Figure 3. Macroscopic view of the excised mass story $(8,9)$. The absence of a penetrating trauma story in this case, and the fact that the dimensions are large enough, did not primarily suggest a preoperative foreign body reaction, but it may not be possible to distinguish giant size foreign body reaction from soft tissue benign tumour preoperatively (10). Excisional biopsy of the lesion allows pathological evaluation and diagnosis to be confirmed and is therapeutic. Simple excision is curative.

Although the 58-year-old male patient has no history of penetrating trauma or prior surgery, we managed to get a giant size foreign body reaction. If the mass detected is independent of the aetiology, the foreign body should be considered for the differential diagnosis. Thus, it can be successfully treated with complete excision of the mass.

\section{Ethics}

Informed Consent: Informed consent is taken from the patient for the case presentation below.

Peer-review: Externally peer-reviewed.

Authorship Contributions: Authorship Contributions: Surgical and Medical Practices - E.C., A.B.; Concept - E.C.; Design - E.C., A.B.; Data Collection or Processing - E.C.; Analysis or Interpretation - E.C., A.B.; Literature Search - E.C., A.B.; Writing - E.C., A.B.

Conflict of Interest: No conflict of interest was declared by the authors.

Financial Disclosure: The authors declared that this study received no financial support.

\section{References}

1. Johnson J, Kilgore E, Newmeyer W. Tumorous lesions of the hand. J Hand Surg Am 1985; 10: 284-6.

2. Agarwal A, Prakash M, Gupta P, Tripathy S, Kakkar N, Srinivasan R, et al. Soft tissue masses of hand: a radio-pathological correlation. Radiol Res Pract 2015; 2015

3. Lee $\mathrm{CH}$, Tandon A. Focal hand lesions: review and radiological approach. Insights imaging. 2014; 5: 301-19.

4. Mavrogenis AF, Panagopoulos GN, Angelini A, Lesenský J, Vottis C, Megaloikonomos PD, et al. Tumors of the hand. Eur J Orthop Surg Tr 2017; 27: 747-62.

5. Zaidenberg EE, Roitman P, Gallucci GL, Boretto JG, De Carli P. ForeignBody Reaction and Osteolysis in Dorsal Lunate Dislocation Repair With Bioabsorbable Suture Anchor. Hand (NY) 2016; 11: 368-71.

6. Fasano Jr FJ, Hansen RH. Foreign body granuloma and synovitis of the finger: a hazard of ring removal by the sawing technique. J Hand Surg Am 1987; 12 621-3.

7. Robinson PM, Muir LT. Foreign body reaction associated with Artelon: report of three cases. J Hand Surg Am 2011; 36: 116-20.

8. Levine WN, Leslie BM. The use of ultrasonography to detect a radiolucent foreign body in the hand: a case report. J Hand Surg Am 1993; 18: 218-20.

9. Hung Y, Hung L, Griffith J, Wong C, Ho P. Ultrasound for the detection of vegetative foreign body in hand--a case report. Hand Surg 2004; 9: 83-7.

10. Kamaci S, Ergen FB, Leblebicioglu G. Lipoma arborescens in the extensor tendon sheath of the hand secondary to foreign body reaction. J Hand Surg Eur Vol 2015; 40: 751-3. 